\title{
XXVII. A new instrument for comparing linear measures
}

\section{M. de Prony}

To cite this article: M. de Prony (1816) XXVII. A new instrument for comparing linear measures, Philosophical Magazine Series 1, 47:214, 125-130, DOI: $10.1080 / 14786441608638812$

To link to this article: http://dx.doi.org/10.1080/14786441608638812

$$
\text { 曲 Published online: } 27 \text { Jul } 2009 .
$$

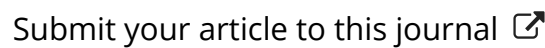

Џ Article views: 2

Q View related articles 5 
of a great number of solar observations only by 7.65 of a second. In this calculation, I have supposed the mean parallax of the sur equal to $8 \cdot 59^{\prime \prime}$, corresponding with that which 1 have deduced from my theory of the moon, comprared with the inequality of the lumar motion, known by the name of parallactic ineguality, and which MI. Burckhardt has determined by means of a very great number of olscrvations. M. Ferère, a learned Spanish astrononer, has lately confined this parallax by a new investigation of the transit of Veuts in 1769 ; in which, by his own olservations, he has corrected the latitude and longitude of plaees where this transit has been observed in America. 'The agreement between all these computations determined by phrenomena so vague, is an additional confirmation of the principle of universal gravitation.

XXVII. A new Instrument for comparing Linear Measures. By M. DE PRONY*.

$\mathrm{T}$

He comparison of linear measires, when great accuracy is necessary, requires careful and delicate operations, as well as the use of inachnery not generally employed in commercial concerns, and dillicult to be procured. I have already published the description of an instrument of this lind, invented and made by M. Lekoir, member of the Board of Longitude, which is as perfect as can be wished; but its expense and size put it out of the power of common obscrvers to procure, and render it uscless to trivellers, who wish to know the proportion betreen some given standard, and the linear measures of any country through which they may pass.

I have had made for my onn use, a compurer, which joins the two advatatios of oeconomy and portability: all the pieces of which it is composed may be fitted into a box of the size of a quarto book. The uearest piart is a microccope; but even this requires nothing biterent from those with which observers are commosily furhished. In general it is only necessary to be at the experise of making three auditional pieces, which I shall describe presently.

The properties and use of my comparer are founded on the progress which the art of dividing a right line has made within the last half century. This instrument has therefore, independently of the above advantages, that of requiring no verniter nor micrometer screw, \&c.

It is well known that M. Richer, one of the first artists of Paris for the construction of mathematical instruments, has

$$
\text { * Eummenicated ly Dr. Fran: }
$$


long heen in the habit of making divisions on glass that are very clear and minute at the distances of 100 ths of a millimeter, and cven less*. A glass having two or three millimeters with the tlivision of one of them into 100 parts costs at his house, ten or twelve francs.

Some foreign artists have also succeeded in this kind of work. 1 procured in my travels in Italy, two small dises of glass on each of which are two millimeters, the one divided into ten and the other into a lundred equal parts. I had them of M. Capello of Turin, an artist who is equally celchrated for his inventive mind and his ability to execute what he has conreived.

I know also at Paris an amateur, M. Le Baillif, who applies all the leisure moments which his situation under government affords, to the cultivation of the sciences; and who among his other talents possesses that of dividing a right line on glass in a rare and remarkable manner. He has had the kindness to trace for me on a small dise of glass 21 tenths of a millimeter; ten of which are subdivided into $100 \mathrm{dths}$ and $200 \mathrm{dths}$. These divi*ions of $200 \mathrm{dths}$ are very neat, and perfectly visible with a microscope magnifying 100 times.

Those persons who wish to possess a comparer like mine, enght first to procure one of thesc glasses on which a right line is divided into as many millimeters as they please, and one of these millineters subdivided into 100dths. The first $10,20,30$, \&c. strokes of this subdivision into 100 , are prolonged, and the $5,15,25$ th, \&c. should be also prolonged, but less than the former, in order that the tenths and half-tenths of a millimeter may be distinguished at the first glance of the eve.

The piece of which I have just spoken must he fixed at one of the extremities of a brass rule, the lengths of the strokes of the divisions being perpendicular to the length of the rule which carries at its extremity a steel stud, intended to be put in contact with the ends of the linear measures which we may have to compare.

Another fixed stud must be screwed and held very solidly on * board or a table which holds the measures and all the apparatus.

When we wish to compare any two linear measures, one of then must first be placed in such a way that one of its extremities

* I have a micromcter screw made by this able artist, two decimcters in length. He engaced to cut these divisions at intervals of a half millimetcr, and he succeeded so well that the most rigid proofs could not discover the least inequality that was sensible throughout the whole 200 divisions. This is one of the most difficult taslis that can be undertaken of this kind. 
may rest against the fixed stud, and its other and in contact with the movenhle one; the whole heing so disposed, that the axes of the rules, the axis of the lincar measures, and the midrlle poines of the divisions on the glass are exactly in right lines. The microscope hehl by the same board, or the same table on which the other parts of the apparatus and the linear mearnes are laid, must be so pointed to one of the divisions on the glass, that after some preliminary trials, or first approximative data, on the ratios of the linear measures, we may be certain that the second measure to be compared, when we have made the same dispositions respecting it, will bing the 100 dths or $200 \mathrm{dth}$ of a millimeter under a stroks, which is afterwards to be deternined when placed in the focus of the mieroscope; which microscope, wiben the collimation has been established, with respect to the beginning of the divisions, must be kept immoveable during the comparison of the two linear measures.

The apparatus is to be disposed in such a way, that the girss carring the divisions may be placed between the reflecting mirrcr of the microscope and the object lens; and if we wish to adjust the focus-line to the line at the beginning of the divisions, we make the supports of the microscope to abut against the point of a fixed horizontal screw and nut; this suoport being made to slide along a rule parallel to the linear measures. The parallelisin between the focus-line and the strokes of the division is easily obtained by the hand, by causing the microscope to turn roumd in the circular horizontal ring in which it is inclosed.

The collimation of the focus-line with cae of the strolses on the divisions on the glass being thus well established, we remove the first linear measure, and replace it with the second, by resting the noveahle stud against one of its ends, and making its other end to abut against the fixed stud. The point of collimation will change, if the measures are not equal ; and their difference of length will be given by the quantity that the second measure shall have removed the first stroke of the divisions fiom the division on which the collimation was established for the first; which quantity of removal is measured by the number of millimeters, and $100 \mathrm{dths}$ of a millimeter, contained between the $\mathrm{two}$ successive points of collimation.

I return to the line placed in the focus of the microscope. It is easy to conceive the extreme funeness that this line must have, since it ought to appear on the space contained betwecn two consecutive divisions on the glass; which spaces are 100dths of millimeters, and so as to permit their evaluation by estimation to 1000 dths of a millimeter. I believe it would be in vain to attempt to perform this by placing a wire in the focus; and that the finest of those that are commonly adapted to telescopes, 


\section{A new Instrument for comparing Linat Mltisures.}

either for the purposes of survering, or for those of actronomy, cover spaces mmeh too great to allow of a sinilar esination, although they only undergo the magnifying purer of the eyeglass. I received from: M. Breguet, member of the bonal of Longitude, a phatina wire made in England by an ingenious process. This wire had been passed throngh a hole when enveloped in a covering of silver; and wherp the compound of the two metals had been reduced to its greatest fmeness, the silvo was disolved, and the platina wie left uncovered. The maker had written on the piece which contained the wire of which I syeak the number 6000 , to indicate that its dianeter is $\frac{10}{6} \mathrm{dth}$ of a fraction of an English foot, whicin M. Bregnet thinks is a line. If he has been rightly informed in this respect, there is an enormone miscalculation in the evaluation of the laker; for his wire, when stretched and put in contact whith the division of 100 dehs of a millimeter, covered the interval between two strokes, and the strokes themselves. Its nagnitude is tirerefore more than $0 .(11$ nillincter, whilst the English evaluation only makes it 6.00635 millimeter : and if, as 1 an inched to believe, it is not lingloths of a line, but only 6 , Mhiths of an inch, that he intaded to indicate by the number 0 bof whiten on the sibe of the wre, there is still an er-

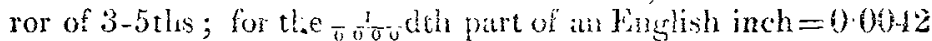
millimeter.

This wire, which has moliaby the greatest degree of funeness that cais be atcained in the present siate of the arts, does not therefore give us the mont dichate line that an be rendered

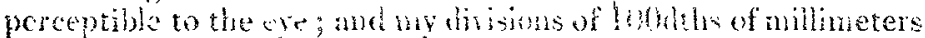
on ylass sere ats a protit of this. The thickness of each line of this divinon is ony aboth the thind of the length of the interval contaned betwent tho innethely aljoming strokes; so that

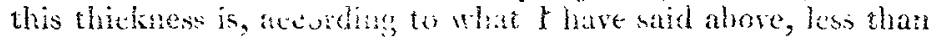
the third of the dimetes of the lisploh platina vire. For these reasons I have deteminel not to mut the wire in the focus of the microscope, but to put a pite of plain glass there, on which M. Ricler has tran fur hur two lines at right angles, of such a degree of finenes and notan, that when one of these lines projects itgelf betwen two strules of the divisions on glass, the proportan between its dintances fom each adjoining stroke may easily le entimated. This experitent affords alwo the ativantage of great solidity, and that of renlering the appifation of at vernier to the apparatus unite easy by having on the glasi in the focus ten parallel strone, which should cover 9 or 11 of tire divisions of 100 diths of a millimeter.

It is mnecessary to trouble ourselves aluout the loss of light occasioned by this giass in the focus; for notwithetanding its interposition betwou the eye and the object, an intensity of light 
A new Instrument for comjaring Linear Measurts. 129

that the eye still supports very well, causes the strokes marked on the glass, bearing the divisions into lo0dths of a millimeter, to disappear. It has sometimes happened, that 1 have intercepted a part of this light by placing my hand before the reflecting mirror: and I have remarked, that in seeking by the vertical motion of this hand the proper position for the degree of light that I wanted, I made the point of collimation to vary within the limits of about $\tau_{10}^{\frac{1}{0}} \mathrm{dth}$ of a millimeter. According to this observation it is necessary, whilst we are comparing the linear measures, to leep the quantity of light thrown on the divided glass in the interior of the microscope always in the same state.

The accuracy and convenience of my new comparer has already been submitted to frequent trials. The ratios of some of the linear measures on which it has been tried had been determined with the great comparer of $\mathrm{M}$. Lenoir, and the agreement between the fesults furnished by both instruments has been very satisfactory. Among the operations from which these results are derived there is one that I made with my colleagues Messrs. Bouvard and Arrago. One of the objects of comparicon was the standard platina metre of the observatory.

\section{To Mr. Tilloch.}

Dear Sir,- I $\mathrm{N}$ consequence of the observations made in the preceding paper, on the size of the very fine platina wire so ingeniously contrived and made by Dr. Wollaston, I deemed it proper to inform him that $I$ intended to present you with a translation of M. de Prony's Memoir for publication in your valuable Marazine. I have accordingly been favoured by that gentleman with the subjoined information on the subject, which not only explains the difficulty, but informs us of the manner in which the wire is produced, and the mode arlopted for estimating its size. The portions of an inch called lines, which the French scientific gentlemen use very commonly, are rarely employed in this country: it was therefore very natural to conclude, that M. Breguet must have made some mistake, in the statement of its dimensions which he carried back with him to France, and communicated to $M$. de Prony.

$$
\begin{aligned}
& \text { I remain, dear sir, } \\
& \text { Yours, \&c. \&c. }
\end{aligned}
$$

Curist's IIospital, Feb. 2.0, 1816.

T. S. Evans.

r When Mr. Breguet was in London, he received from Dr. Wollaston a specimen of platina wire $\frac{1}{\sigma 0} \overline{0}$ dth of an inch in diameter.

Vol.47. No.214. Fel.1816. I I I 
130 Remarks on the Grological Sictch of Cumberland, Eפr.

"The data from which Dr. W. infers the dimensions of so tmall a wire may serve as a means of estimating the accuracy of M. Prony's method when applied to the measure of such olijects.

"A wire of pure platina is dram till ten grains of it messure 24 inches, so that its dianeter is thus known to be To dith of all inch.

"A portion of this wire is then coated with silver cast round it in a cylindrical mould, (about 3 ths of an inch in diameter).

"The cylinder is then drawn till each inch is clongated to 400 inches, in which state the diameter of the platina is known to be reduced in the proportion of the square root of 400 or twenty-fold: so that its diameter is then $\frac{1}{400}$ dth of an inch.

"If any portion of the silver wire be then further drawn till one jnch measures nine inches, the platina wire within it is then reduced to $\frac{1}{3} \mathrm{~d}$ part of its last diameter, and is consequently $60 \mathrm{dth}$ of an inch in thickness.

"If the silver wire be then dissolved by nitric acid, the dianeter of the platina which remains undissolved (although kept perfectly clean) could not with confidence be pronounced inaccurate by a mensuration in which its dimensions were at first presumed to be $\frac{7}{7} \frac{1}{4}-\bar{v} d t t_{2}$ of an inch.
Feb. 20, 1816.
"W. H. WOLLAsTON."

\section{Remarks on the Geological Sietch of a Part of Cum- lerland and $\dot{W}$ estmortand.}

\section{To Mr. Tilloch.}

Sin, - $I_{N}$ your Magazine for 1 .st month, (p. 41,) in an article entitled "A Geological Sketch of a P'art of Cumberland and Wes:inoreland," your correspondent notices as a fact, that carbonate of strontites has been found in the basalt of the Giant's Canseway. This is a circumstance that has frecuently been noticed to me, and specimens have been shown me, as carbonate of strontites, which I have uniformly found to be carbonate of lime. It is nothing uncommon to mistake the one substance for the other, the carbonate of strontites from Braunsdorf in Saxony having long been considered as the hard carbonate of lime among: the German mineralogists.-I should therefore be glad to know from your correspondent, through the medium of your Magazine, whether the specimen he refers to has been submitted to analysis.

Your correspondent likewise notices that the clay-slate and

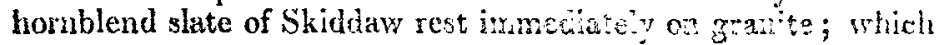

